\title{
Some pharmacognostic studies of the cogon grass Imperata cylindrica from Mizoram, India
}

\author{
P.B. Lalthanpuii, Zarzokimi, K. Lalchhandama* \\ ${ }^{\text {I}}$ Department of Zoology, Pachhunga University College, Mizoram University, Aizawl 7960oI, Mizoram, India
}

\begin{abstract}
Cogon grass Imperata cylindrica is a perennial grass belonging to the family Poaceae, and the rhizome-root portion of which is used for the treatment of bacterial infections, ringworms and other skin infections. Among the Mizo people they are directly consumed or juiced for the treatment of intestinal infection. Its chemical and biological properties are poorly documented. In this study, a methanol extract of the rhizome-root was prepared by hot extraction in a Soxhlet apparatus. Standard chemical tests were conducted. The presence of alkaloids, carbohydrates including reducing sugars, phytosterols, tannins, saponins and proteins were confirmed as the major bio-compounds. Free radical-scavenging activities were also determined. The plant extract indicated concentration-dependent scavenging activity on DPPH with an inhibitory concentration $\left(\mathrm{IC}_{50}\right)$ of $2.14 \mu \mathrm{g} / \mathrm{ml} . \mathrm{H}_{2} \mathrm{O}_{2}$ was similarly scavenged, in which the $I_{50}$ was $2.221 \mu \mathrm{g} / \mathrm{ml}$. Our results suggest that $I$. cylindrica has important medicinal values.
\end{abstract}

Key words: Imperata cylindrica, alkaloid, DPPH, $\mathrm{H}_{2} \mathrm{O}_{2}$, phytosterol, saponin, tannin.

\author{
Received 26 July 2018 \\ Accepted 24 August 2018 \\ *For correspondence $\bowtie$ : \\ chhandama@gmail.com
}

\section{Introduction}

Cogon grass Imperata cylindrica (L.) Räuschel belongs to a perennial rhizomatous grass and is is native to Southeast Asian and Australian regions. It serves as an important construction material for thatching in many Asian tribal houses because of its water-tight and tough fibre. It is also used for making papers, weaving mats, bags, and organic raincoats. In Japan it is grown as an ornamental grass; most popularly as Red Baron or Japanese Blood grass. Its rhizome and flowers are recognised to have antibacterial, anticoagulant (styptic), antifever (antipyretic), diuretic, salivating (sialagogue), skin softening (emollient), and soothing (tonic) properties. $^{1,2}$ The roots are used as remedy for nosebleed (epistaxis), blood urine (haematuria), blood vomit (haematemesis), oedema, and jaundice. Compounds isolated from the leaves reportedly show neuro-protective ${ }^{3}$ and vasodilative effects. $^{4}$

Cogon grass is disgracefully nominated in the list of 100 "World's Worst" invaders by the IUCN Invasive Species Specialist Group. It is also included in the Federal Noxious Weeds List from the United States Department of Agriculture. It has been reported from 73 countries as a major invasive plant, and weed to about 35 different crops. Majority of the invasion are recorded in the tropical wet climate. $^{2,5}$ In West and Central Africa and in the 
United States, the its invasiveness is so extensive that large hectares of agricultural farms are completely deserted every year. The aggressiveness is because of its ability to overtake other plants including with crops and native plants for nutrients and water, and for this it can adapt to almost any kind of environmental conditions. ${ }^{6,7}$

The Mizo people has long used the rhizome in infections for its effective antibacterial activity such as in skin injury, cholera, dysentery and diarrhoea. In addition, it is sometimes used as in skin infections such as in ringworms. It is also a good anthelmintic agent. The rhizome is crushed and juiced, or directly chewed to remove intestinal worms. ${ }^{8}$ In Mizoram, the plant propagates very quickly during Monsoon after slash-and-burn (jhum) cultivation.

\section{Materials and Methods}

\section{Plant specimen}

Cogon grass were collected during AugustOctober in 2017 from a forest in Ngopa village, Champhai district, Mizoram, India, which is located between $23.8861^{\circ}$ latitude north and $93.2119^{\circ}$ longitude east. Rhizomes were harvested only from the fully mature and flowering plants. A herbarium specimen was prepared for the whole plant which was identified at the Botanical Survey of India (BSI), Shillong, Meghalaya, and is maintained at the herbarium section of the Department of Botany, Pachhunga University College, Aizawl, Mizoram (accession no. PUC-I-18-01). The rhizomes were washed and then dried in shade at $21-27^{\circ} \mathrm{C}$.

\section{Chemicals and reagents}

All chemicals and reagents used were standard analytical grades procured either from Merck, India, or HiMedia Laboratories Pvt. Ltd.

\section{Extraction}

The dried plant specimens were ground to course powder using mortar and pestle. The plant powder was weighed and loaded $n$ batches into the thimble of Soxhlet apparatus having a $5 \mathrm{~L}$ capacity. Methanol was used as the extraction solvent, and plant extract was prepared using continuous hot extraction. The extracts were concentrated by evaporating through a chiller unit. The crude plant extracts were obtained as semi-solid mass, and were preserved at $4^{\circ} \mathrm{C}$ for further analysis.

\section{Chemical detection}

The phytochemical components of $I$. cylindrica rhizome were analysed using standard detection protocols. In summary, the alkaloids were tested by Mayer's test, Dragendroff's test, Wagner's test and Hager's test; the carbohydrates by Molisch's test, Fehling's test and Benedict's test; the phytosterols by Liebermann-Burchard's test and Salkwoski reaction; the glycosides by Legal's test, Baljet's test and Borntrager's test; the tannins by iron(III) chloride $\left(\mathrm{FeCl}_{3}\right)$ test, potassium dichromate $\left(\mathrm{K}_{2} \mathrm{Cr}_{3} \mathrm{O}_{7}\right)$ test and lead acetate test; the saponins by foam test; the reducing sugars by Fehling's test and Benedict's test; the flavonoids by Shinoda test and zinc hydrochloride $(\mathrm{ClHZn})$ reduction test; and the proteins/ amino acids by Millon's test and ninhydrin test.

\section{Free radical-scavenging activity}

The free radical-scavenging potentials of the plant were tested by targeting DPPH and $\mathrm{H}_{2} \mathrm{O}_{2}$. DPPH test was done after the method of Blois (1958). ${ }^{9}$ In brief, different concentrations such as $10,20,40,60,80$, to $100 \mu \mathrm{g} / \mathrm{ml}$ were prepared for of the plant extract and butylated hydroxytoluene (BHT). After adding $0.5 \mathrm{ml}$ of DPPH solution, they were incubated at $37 \pm 1^{\circ} \mathrm{C}$ for 30 minutes. Absorbance was measured at $517 \mathrm{~nm}$ in a UV-Vis spectrophotometer. The percentage of inhibition was calculated by comparing the absorbance values of the test samples with those of the controls.

$\mathrm{H}_{2} \mathrm{O}_{2}$ scavenging activity was studied after the method of Ruch et al. (1989). ${ }^{10}$ Different concentrations $(10,20,40,60,80$, to $100 \mu \mathrm{g} / \mathrm{ml})$ of the extract 
and ascorbic acid were added separately to the hydrogen peroxide solution $(0.6 \mathrm{~mL}, 40 \mathrm{mM})$. After ten minute of incubation, the absorbance was taken at $230 \mathrm{~nm}$ against a blank solution containing the phosphate buffer without hydrogen peroxide.

The inhibition percentage (I) was calculated using the formula:

$$
\% \text { Inhibition }=\left[\frac{A_{C}-A_{S}}{A_{C}}\right] \times 100
$$

Where $A_{C}$ is the absorbance of control and $A_{S}$ is the absorbance of the sample or standard.

The inhibitory concentration, $I C_{50}$ was calculated from the linear regression graphs.

\section{Results}

\section{Pbytochemicals}

Important chemical compounds present in the rhizome of $I$. cylindrica are shown in Table 1 . Mayer's test indicated the presence of alkaloids. Fehling's test and Benedict's test indicated the presence of carbohydrates and reducing sugars. Salkwoski reaction showed the presence of phytosterols. $\mathrm{K} 2 \mathrm{Cr} 3 \mathrm{O} 7$ test and lead acetate test showed the presence of tannins. Millon's test showed the presence of proteins and amino acids.

\section{Free radical-scavenging activity}

The DPPH-scavenging activity of $I$. cylindrica extract is shown in Figure 2. The activity increased from 10 to $100 \mu \mathrm{g} / \mathrm{ml}$ of the plant extract and the reference compound. Both the extract and BHT showed linear concentration-dependent activity, i.e. the higher the concentration the more the scavenging activity. BHT appeared to be more potent than the plant extract at all concentrations tested. At the lowest and highest concentrations, the plant extract scavenged $46.35 \%$ and $62.11 \%$ of DPPH respectively; while $\mathrm{BHT}$ could scavenge $51.72 \%$ and $85.34 \%$ at the same concentrations. From the linear regression graph, the plant extract showed an $\mathrm{IC}_{50}$ of $2.22 \mu \mathrm{g} / \mathrm{ml}$, while that of BHT was $0.73 \mu \mathrm{g} / \mathrm{ml}$.

The $\mathrm{H}_{2} \mathrm{O}_{2}$-scavenging activity is depicted in Figure 2. A concentration-dependent effect was apparent in the scavenging activity. The highest scavenging activity was shown by $100 \mu \mathrm{g} / \mathrm{ml}$ which scavenged $-85.71 \%$ of, while the lowest scavenging activity was shown by $10 \mu \mathrm{g} / \mathrm{ml}$ that scavenged $91.43 \%$ of $\mathrm{H}_{2} \mathrm{O}_{2}$. Ascorbic acid scavenged $-100 \%$ and $84.62 \%$ at $100 \mu \mathrm{g} / \mathrm{ml}$ and $10 \mu \mathrm{g} / \mathrm{ml}$ respectively. The $\mathrm{IC}_{50}$ of the plant extract was $2.57 \mu \mathrm{g} / \mathrm{ml}$, while that of the standard ascorbic acid was $2.1 \mu \mathrm{g} /$ $\mathrm{ml}$, revealing that they are almost equally efficacious.

\section{Discussion}

Important bioactive phytochemicals were confirmed in the present study including alkaloids, carbohydrates including reducing sugars, phytosterols, tannins, saponins and proteins/amino acids in the rhizome of $I$. cylindrica. These compounds are well established bioactive compounds having a variety of pharmaceutical applications. Alkaloids are the source of pharmaceutical drugs such as antimalarial (quinine), antihistamine (ephedrine), anticancer (homoharringtonine), vasodilatory (vincamine), antiarrhythmic (quinidine), analgesic (morphine), antibiotic (chelerythrine), antihyperglycaemic (piperine) drugs, as well as psychotropic (psilocin), and stimulant compounds (cocaine, caffeine, nicotine, theobromine). ${ }^{11}$ Phytosterols are powerful modulators of the immune system and they are used for prevention biochemical malfunctions in cells that can otherwise emerge as cancers and autoimmune disorders. The most successful use is as cholesterolreducing agents in the blood circulation. ${ }^{12}$ Saponins exhibit a wide range of pharmacological activities including antidiabetic, antiparasitic, antiinflammatory, antifungal, expectorant, hypocholesterolemic, hypoglycaemic, immunomodulatory, molluscicidal, and vasoprotective activities. ${ }^{13}$

Many of the cellular metabolic disorders are due to free radicals. Free radicals such as reactive oxygen and nitrogen species are produced during 
Table 1 | Phytochemical analyses of the methanol extract of $I$. cylindrica root.

\begin{tabular}{|c|c|c|c|}
\hline SI. No. & Compounds & Phytochemical test & Present/Absent \\
\hline \multirow[t]{4}{*}{1.} & \multirow[t]{4}{*}{ Alkaloids } & Mayer's test & + \\
\hline & & Dragendroff's test & - \\
\hline & & Wagner's test & - \\
\hline & & Hager's test & - \\
\hline \multirow[t]{3}{*}{2.} & \multirow[t]{3}{*}{ Carbohydrates } & Molisch's test & - \\
\hline & & Fehling's test & + \\
\hline & & Benedict's test & + \\
\hline \multirow[t]{2}{*}{3.} & \multirow[t]{2}{*}{ Phytosterols } & Liebermann-Burchard's test & - \\
\hline & & Salkwoski reaction & + \\
\hline \multirow[t]{3}{*}{4.} & \multirow[t]{3}{*}{ Glycosides } & Legal's test & - \\
\hline & & Baljet's test & - \\
\hline & & Borntrager's test & - \\
\hline \multirow[t]{3}{*}{5.} & \multirow[t]{3}{*}{ Tannin } & $\mathrm{FeCl}_{3}$ test & - \\
\hline & & $\mathrm{K}_{2} \mathrm{Cr}_{3} \mathrm{O}_{7}$ test & + \\
\hline & & Lead acetate test & + \\
\hline 6. & Saponins & Foam test & + \\
\hline \multirow[t]{2}{*}{7.} & \multirow[t]{2}{*}{ Reducing sugars } & Fehling's test & + \\
\hline & & Benedict's test & + \\
\hline \multirow[t]{2}{*}{8.} & \multirow[t]{2}{*}{ Flavonoid } & Alkaline reagent test & - \\
\hline & & $\mathrm{ClHZn}$ reduction test & - \\
\hline \multirow[t]{2}{*}{9.} & \multirow[t]{2}{*}{ Proteins and amino acids } & Millon's test & + \\
\hline & & Ninhydrin test & - \\
\hline
\end{tabular}

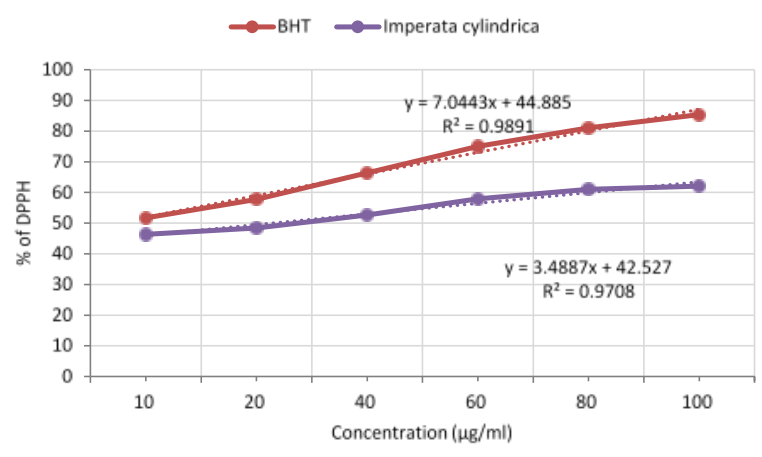

Figure 1 | DPPH-scavenging activity of $l$. cylindrica and butylated hydroxytoluene.

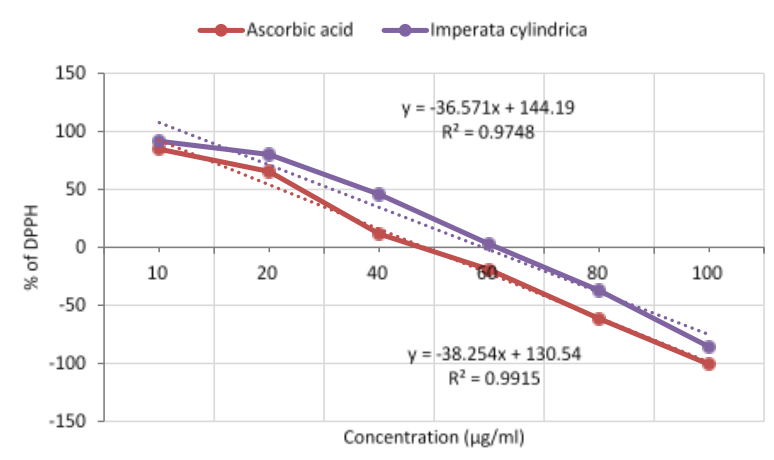

Figure 2 | $\mathrm{H}_{2} \mathrm{O}_{2}$-scavenging activity of I. cylindrica and ascorbic acid. 
normal cellular metabolism in the body, and they tend to cause damage to DNA, lipids, proteins, and other vital biomolecules. They are able to capture free electrons from biomolecules to render them structurally and functionally altered. ${ }^{14}$ Hydrogen peroxide particularly powerful for its capability to cross cell membranes and oxidize cellular compounds such as nucleic acids, lipids, proteins resulting in the deactivation of several genes. ${ }^{15}$ The overall effect is known as oxidative stress, which is therefore deeply linked with several gene-based such as cardiovascular, neurodegenerative, cancer and even aging. ${ }^{16}$

Free radicals are removed or neutralised by antioxidants and antioxidant enzymes to maintain oxidation equilibrium in cells. We have innate antioxidant defenses such as superoxide dismutases, hydrogen peroxide-removing enzymes, metal binding proteins, but they are insufficient to attack the overwhelming oxidation in the cells. For this reason, antioxidants from external sources are essential for preventing the oxidation dangers. ${ }^{17}$ These molecules can not only scavenge free radicals alone but also control antioxidant and detoxifying enzymes, modulation of redox cell signaling and gene expression, by which they maintain the body balance of oxidation and free radical removal. ${ }^{18}$

Antioxidants from dietary sources are the main sources of defense in cellular oxidation. The importance of medicinal plants in particular are highly appreciated as they are cheap and readily available. ${ }^{17,19}$ Therefore, understanding the ability of plants to attack free radicals is a crucial investigation for establishing their therapeutic tendency. Thus, they are important agents in the prevention and perhaps treatment of serious diseases like cancer. ${ }^{20,21}$ The present study also shows that I. cylindrica has a potential property in this regime for its strong free radical-scavenging activity, and in fact more potent than the standard compound BHT, and equally potent as ascorbic acid.

\section{Acknowledgement}

The authors are grateful to Science and Engi- neering Research Board (SERB), Government of India, for the research project no. EMR/2016/004053 of 23/03/2017. PBL is a Junior Research Fellow under the project.

\section{References}

I. Townson, J.K. (1991). Imperata cylindrica and its control. Weed Abstracts, 40 (II): 457-468.

2. CABI (2018). Imperata cylindrica (cogon grass). In: Invasive Species Compendium. www.cabi.org. Oxon (UK): CAB International, online.

3. Yoon, J.S.; Lee, M.K.; Sung, S.H.; Kim, Y.C. (2006). Neuroprotective 2-(2-phenylethyl) chromones of Imperata cylindrica. Journal of Natural Products, 69 (2): 290291.

4. Matsunaga, K.; Shibuya, M.; Ohizumi, Y. (1994). Graminone B, a novel lignan with vasodilative activity from Imperata cylindrica. Journal of Natural Products, 57 (I2): 1734-1736.

5. Lusweti, A.; Wabuyele, E.; Ssegawa, P.; Mauremootoo, J. (20II). Imperata cylindrica (Cogon Grass). keys.lucidcentral.org. BioNET-EAFRINET.

6. MacDonald, G.E. (2004). Cogongrass (Imperata cylindrica)-Biology, ecology, and management. Critical Reviews in Plant Sciences, 23 (5):367-380.

7. Koger, C.H.; Bryson, C.T. (2017). Effect of Cogongrass (Imperata cylindrica) extracts on germination and seedling growth of selected grass and broadleaf species. Weed Technology, 18 (o2): 236-242.

8. Sawmliana, M. (2013). The Book of Mizoram Plants. Aizawl (India): P. Zakhuma, p. 143.

9. Blois, M.S. (1958). Antioxidant determinations by the use of a stable free radical. Nature, I8I: II99-I200.

Io. Ruch, R.J., Cheng, S.J., Klaunig, J.E. (1989). Prevention of cytotoxicity and inhibition of intercellular communication by antioxidant catechins isolated from Chinese green tea. Carcinogenesis, Io: 1003-1008.

II. Cordell, G. A., Quinn-Beattie, M. L., Farnsworth, N. R. (200I). The potential of alkaloids in drug discovery. Phytotherapy Research, I5(3): 183-205.

I2. Bouic, P. J. (200I). The role of phytosterols and phytosterolins in immune modulation: a review of the past Io years. Current Opinion in Clinical Nutrition \& Meta- 
bolic Care, 4(6): 47I-475.

13. Lacaille-Dubois, M. A., Melzig, M. F. (2016). Saponins: Current progress and perspectives. Planta Medica, $\mathbf{8 2}$ (I8): 1495-1495.

I4. Sies, H., Berndt, C., Jones, D. P. (2017). Oxidative stress. Annual Review of Biochemistry, 86: 715-748.

I5. Gaschler, M.M., Stockwell, B.R. (2017). Lipid peroxidation in cell death. Biochemical and Biophysical Research Communications, 482: 419-425.

16. López-Alarcón, C., Denicola, A. (2013). Evaluating the antioxidant capacity of natural products: A review on chemical and cellular-based assays. Analytica Chimica Acta, 763, I-IO.

17. Das, U., Behera, S. S., Pramanik, K. (2017). Ethno-herbal -medico in wound repair: An incisive review. Phytotherapy Research, 31(4): 579-590.
18. Pisoschi, A. M., Pop, A. (2015). The role of antioxidants in the chemistry of oxidative stress: a review. European Journal of Medicinal Chemistry, 97: 55-74.

19. Lee, M. T., Lin, W. C., Yu, B., Lee, T. T. (2017). Antioxidant capacity of phytochemicals and their potential effects on oxidative status in animals-A review. AsianAustralasian Journal of Animal Sciences, 30(3): 299308.

2o. Gholamian-Dehkordi, N., Luther, T., Asadi-Samani, M., Mahmoudian-Sani, M. R. (2017). An overview on natural antioxidants for oxidative stress reduction in cancers; a systematic review. Immunopathologia Persa, 3 (2): eI2.

2I. Meybodi, N. M., Mortazavian, A. M., Monfared, A. B., Sohrabvandi, S., Meybodi, F. A. (2017). Phytochemicals in cancer prevention: a review of the evidence. Iranian Journal of Cancer Prevention, Io(I): e7219. 